\title{
Time-dependent, species-specific effects of N:P stoichiometry on grassland plant growth
}

\author{
Yuki Fujita • Peter C. de Ruiter • \\ Martin J. Wassen • Gerrit W. Heil
}

Received: 13 December 2009 / Accepted: 8 July 2010/Published online: 25 July 2010

(C) The Author(s) 2010. This article is published with open access at Springerlink.com

\begin{abstract}
N}$ and $\mathrm{P}$ have different eutrophication effects on grassland communities, yet the underlying mechanisms are poorly understood. To examine plant growth in response to the varying (relative) supply of $\mathrm{N}$ and $\mathrm{P}$, we conducted a two-year greenhouse experiment. Five grasses and three herbs were grown with three N:P supply ratios at two overall nutrient supply levels. During the first year the plant growth was relatively low at both high and low N:P supply ratios, whereas during the second year the growth was especially low at a high N:P supply ratio. This second-year low growth was attributed to the high root death rate, which was influenced by a high $\mathrm{N}: \mathrm{P}$ supply ratio rather than by the nutrient supply level.
\end{abstract}

Responsible editor: Michael Denis Cramer.

Y. Fujita $(\bowtie) \cdot$ M. J. Wassen

Department of Environmental Sciences, Copernicus Institute, Utrecht University,

P.O. Box 80115, 3508 TC Utrecht, The Netherlands

e-mail: Y.Fujita@geo.uu.nl

Y. Fujita $\cdot$ G. W. Heil

Section of Landscape Ecology, Department of Biology, Utrecht University,

P.O. Box 80084, 3508TB Utrecht, The Netherlands

P. C. de Ruiter

Biometris, Wageningen University and Research Center, P.O. Box 47, 6700AA, Wageningen, The Netherlands

\section{Y. Fujita}

Team Ecology, KWR Watercycle Research Institute, Groningenhaven 7,

3433PE Nieuwegein, The Netherlands

e-mail: Yuki.Fujita@kwrwater.nl
Species responded differently, especially in P uptake and loss at a high $\mathrm{N}: \mathrm{P}$ supply ratio. Each species seemed to have a different strategy for P limitation, e.g. an efficient $\mathrm{P}$ uptake or a high $\mathrm{P}$ resorption rate. Species typical of P-limited grasslands had neither better $\mathrm{P}$ uptake nor better $\mathrm{P}$ retention at a high $\mathrm{N}: \mathrm{P}$ supply ratio. This study quantitatively demonstrates an increased plant root death triggered by strong $\mathrm{P}$ limitation. This finding indicates a possible extra effect of $\mathrm{N}$ eutrophication on ecosystem functioning via changed N:P stoichiometry.

Keywords Eutrophication - Plant growth and death . Long-term experiment · Interspecific differences . $\mathrm{N}: \mathrm{P}$ ratio $\cdot$ Nutrient loss

\section{Introduction}

Increased nutrient availability is one of the major causes of degradation among grassland plant communities in Europe. Nitrogen $(\mathrm{N})$ and phosphorus $(\mathrm{P})$ are the two main nutrients responsible for biodiversity decline in grassland ecosystems (Stevens et al. 2004; Bobbink et al. 1998; Wassen et al. 2005). Plant growth can respond differently to $\mathrm{N}$ compared to $\mathrm{P}$ enrichment. $\mathrm{N}$ fertilization immediately increases the biomass of a plant community, whereas the effects of $\mathrm{P}$ fertilization appear slowly (e.g. Güsewell et al. 2002) but last longer (ElKahloun et al. 2003; van der Hoek et al. 2004). On top of that, some species-specific effects have been reported. Legumes, for example, decrease their abundance after $\mathrm{N}$ fertilization (Beltman et al. 2007; 
Kirkham et al. 1996). The contrasting effects of $\mathrm{N}$ and $\mathrm{P}$ fertilization indicate that plants are sensitive to the ratio of nutrients (besides their sensitivity to the overall supply level) but also that these sensitivities may vary among species (Güsewell 2004). It is known that plants maintain a certain stoichiometric balance of elements, such as a N:P, to function properly (Sterner and Elser 2002). Changing the N:P ratio, for instance by adding one element, may induce different responses in different species, which may then affect competition among those species and alter the structure of the community. Several field observations demonstrate the importance of a balance between $\mathrm{N}$ and $\mathrm{P}$ for the functioning of plant communities. Three observations illustrate this: the productivity level at the peak of a hump-shaped curve is lower for P-limited than for N-limited wetlands (Olde Venterink et al. 2003); the species composition shifts from $\mathrm{N}$ - to P-limited grasslands (Güsewell 2004; Olde Venterink et al. 2003; Verhoeven and Schmitz 1991); and endangered species persist better at P- rather than N-limited sites (Wassen et al. 2005).

In search of an explanation for these field observations, a number of greenhouse experiments have been carried out to investigate the morphological and physiological responses of grassland plants to varying balances of N and P (Shaver and Melillo 1984; Ryser et al. 1997; Güsewell 2005a; Macek and Rejmankova 2007). Short-term experiments show that adding N, leading to high $\mathrm{N}: \mathrm{P}$ supply ratios, increases plant biomass, whereas adding $\mathrm{P}$, leading to low $\mathrm{N}: \mathrm{P}$ supply ratios, does not promote plant growth (Güsewell 2005c; Güsewell et al. 2003). Longer-term experiments show contrasting results: after a period of two years, high $\mathrm{N}: \mathrm{P}$ ratios reduce nutrient retention (i.e., the amount of nutrients retained in biomass), whereas low $\mathrm{N}: \mathrm{P}$ ratios do not (Güsewell 2005a; Güsewell et al. 2003). The poor retention at high N:P ratios is assumed to be caused by nutrient loss from roots (Güsewell 2005a), although this relation has not been quantitatively examined. Increased root turnover or root death was also observed in other studies under conditions of P limitation (e.g. El-Kahloun et al. 2003) or upon increased $\mathrm{N}$ availability (e.g. Fransen and de Kroon 2001). However, it remains a matter of speculation whether the root death is caused by the balance between $\mathrm{N}$ and $\mathrm{P}$ availability rather than by the availability of single elements. Nor is it clear what the underlying mechanisms are. Additionally, interspe- cific difference in response to $\mathrm{N}: \mathrm{P}$ ratio has been also suggested by previous greenhouse experiments with a large number of species. Species that react strongly to a change in $\mathrm{N}$ supply do not necessarily also react strongly to a change in P supply (Keddy et al. 2001; Güsewell et al. 2003). This implies that for different species it could be N-or P-limited conditions that are favorable. These interspecific differences in the response to the availability of nutrients also call for research into an explanatory mechanism. Such investigations might fill the gap in understanding how the anthropogenic nutrient enrichment of ecosystems, which is often asymmetric between $\mathrm{N}$ and $\mathrm{P}$ (Lamers et al. 2002; Olde Venterink et al. 2002), may affect communities of plant species.

Hence, the aim of the present study was to examine the effects of the relative availability of $\mathrm{N}$ and $\mathrm{P}$ on plant growth. Concretely, we investigated whether a relatively high $\mathrm{N}$ to $\mathrm{P}$ availability reduces the nutrient retention of plants in a species-specific way. In order to examine both immediate effects and longer term effects, we conducted a two-year greenhouse fertilization experiment with grasses and herbs, including those typical of $\mathrm{P}$ - and N-limited grasslands. We varied both the overall $\mathrm{N}$ and $\mathrm{P}$ supply and the $\mathrm{N}: \mathrm{P}$ supply ratio, enabling us to distinguish the effects due to the supply level from those due to the supply ratio. Based on the prior work, we hypothesized that (1) a high N:P supply ratio reduces plant growth mainly due to high root death and nutrient loss in the second year; and (2) that the high death rate and nutrient loss is influenced by N:P supply ratios rather than by overall nutrient supply levels. Moreover, we hypothesized that (3) different species respond differently to a high $\mathrm{N}: \mathrm{P}$ ratio because of the interspecific difference in root death in the second year. Furthermore, we expected that (4) species that typically occur in P-limited grasslands would have less nutrient loss at a high N:P ratio and thus be better able to cope with $\mathrm{P}$ limitation than other species.

\section{Materials and methods}

Plant species and growth conditions

We used five grass and three herb species, all of which occur naturally in the Netherlands on grasslands ranging from wet to moist. These species were selected on the basis of field data from 381 European grassland sites 
(Wassen et al. 2005; Ertsen 1998; Hölzel unpublished) in order to include species typically found at P- and Nlimited sites in the field. The selected species are Alopecurus pratensis L., Lychnis flos-cuculi (L.) Greuter \& Burdet, Agrostis capillaris L., Festuca rubra L., Lycopus europaeus L., Festuca ovina L., Molinia caerulea (L.) Moench, and Succisa pratensis Moench. The first two and last two species in this list have a significantly more frequent distribution in $\mathrm{N}$ and P-limited grasslands, respectively (chi-square test, $p<0.05$; see Fujita et al. 2010).

Plants were cultivated from seed in a germination chamber starting in May 2007. In June 2007 all seedlings were transplanted to plastic pots filled with c. $500 \mathrm{~g}$ quartz sand and placed in an open greenhouse with a transparent roof and walls of coarse mesh. Plants were fertilized with nutrient solution once a week for two growing seasons. The environmental conditions within the greenhouse-such as temperature, humidity, and light intensity - were similar to the ambient conditions. The fertilization periods lasted 15 weeks in 2007 (starting at the end of June) and 14 weeks in 2008 (starting at the end of March). The chemical composition of the quartz sand was analyzed to ensure that it contained no nutrients or only negligible amounts, which was the case. Every one to three days, demineralized water was poured into trays placed under each pot. Once every three weeks, the pots were leached with demineralized water three times in order to prevent the accumulation of nutrients and toxic compounds. The alignment of the pots was randomized once every three weeks.

Nutrient treatments

We combined two nutrient levels, high and low, and three N:P supply ratios, low (1.7), intermediate (15), and high (135), in a full-factorial design. The resulting six treatments were replicated eleven times. $\mathrm{N}$ was provided as $\mathrm{KNO}_{3}$ and $\mathrm{Ca}\left(\mathrm{NO}_{3}\right)_{2}$, while $\mathrm{P}$ was provided as $\mathrm{KH}_{2} \mathrm{PO}_{4}$. In line with previous studies (Güsewell 2005a,c), the supply of $\mathrm{N}$ and $\mathrm{P}$ was determined such that their geometric means came out equal for all treatments at a distinct supply level (5 mg and $15 \mathrm{mg}$ per plant per year for high and low supply, respectively; Table 1). All other essential elements were supplied at sufficient levels (per pot per year: $25.6 \mathrm{mg} \mathrm{Mg}, 37.1 \mathrm{mg} \mathrm{S}, 5.1 \mathrm{mg} \mathrm{Fe}, 0.01 \mathrm{mg}$ $\mathrm{Cu}, 0.24 \mathrm{mg} \mathrm{B}, 0.55 \mathrm{mg} \mathrm{Mn}, 0.01 \mathrm{mg} \mathrm{Mo}, 0.03 \mathrm{mg}$ $\mathrm{Zn}, 79.8 \mathrm{mg} \mathrm{Ca}, 332 \mathrm{mg} \mathrm{K}$ ). The amount of $\mathrm{N}$ and $\mathrm{P}$ in the high-level treatment at an N:P ratio of 15 is similar to the annual influx of those nutrients occurring in productive wetlands in the Netherlands (Koerselman et al. 1990; Wassen and Olde Venterink 2006).

\section{Measurements}

Before the fertilization period in 2007, five pots of each species were randomly selected and harvested to determine the initial biomass and nutrient content. Dead leaves were collected throughout the experiment. After the 2007 fertilization period, the aboveand below-ground biomass was harvested from five pots per treatment. At the same time, the aboveground biomass of the remaining six pots was clipped approximately $1 \mathrm{~cm}$ above the sand. After the fertilization period in 2008, the above- and belowground biomass of these six pots was harvested. The harvested biomass was sorted into dead and alive parts, dried at $70^{\circ} \mathrm{C}$ for $48 \mathrm{~h}$, weighed, and ground up. Dead roots were separated from living ones based on visual inspection of their color and testing elasticity with a tweezers. After digestion using the Kjeldahl
Table 1 Annual supply of Nitrogen and Phosphorus for six treatments

${ }^{\text {a }}$ Supplied as $\mathrm{KNO}_{3}$

${ }^{\mathrm{b}}$ Supplied as $\mathrm{KNO}_{3}$ and $\mathrm{Ca}$ $\left(\mathrm{NO}_{3}\right)_{2}$. For this treatment, $\mathrm{CaCl}_{2}$ was reduced so that total amount of supplied $\mathrm{Ca}$ is the same for all the treatments

\begin{tabular}{|c|c|c|c|}
\hline \multicolumn{2}{|l|}{ Treatment } & \multicolumn{2}{|c|}{ Nutrient supply (mg pot ${ }^{-1}$ year $^{-1}$ ) } \\
\hline Nutrient supply level & $\mathrm{N}: \mathrm{P}$ supply ratio & $\mathrm{N}$ & $\mathrm{P}$ \\
\hline \multirow[t]{3}{*}{ Low } & Low (1.7) & $6.5^{\mathrm{a}}$ & 3.9 \\
\hline & Intermediate (15) & $19.4^{\mathrm{a}}$ & 1.3 \\
\hline & High (135) & $58.1^{\mathrm{a}}$ & 0.4 \\
\hline \multirow[t]{3}{*}{ High } & Low (1.7) & $19.4^{\mathrm{a}}$ & 11.6 \\
\hline & Intermediate (15) & $58.1^{\mathrm{a}}$ & 3.9 \\
\hline & High (135) & $174.3^{\mathrm{b}}$ & 1.3 \\
\hline
\end{tabular}


procedure $\left(1 \mathrm{~h}\right.$ at $200^{\circ} \mathrm{C}$ and $2 \mathrm{~h}$ at $340^{\circ} \mathrm{C}$ in a mixture of sulfuric acid, salicylic acid, copper sulfate, sodium sulfate, and selenium) (Bremner and Mulvaney 1982), $\mathrm{N}$ and $\mathrm{P}$ concentrations were determined colorimetrically on a continuous flow analyzer (Skalar SA-40). Total contents of $\mathrm{N}$ and $\mathrm{P}$ were calculated for each part of the biomass (above-alive, above-dead, belowalive, below-dead) by multiplying their concentration by the biomass. For each part, when fewer than three samples within a treatment weighed more than $50 \mathrm{mg}$, all samples of the treatment were combined for digestion.

Growth in 2007 (over 15 weeks of fertilization) was calculated by subtracting average initial biomass from biomass (including dead and alive) at the end of the 2007 fertilization period. Growth in 2008 (over 14 weeks of fertilization plus the preceding winter) was calculated by subtracting the average living below-ground biomass in 2007, for each treatment, from the biomass at the end of the fertilization period in 2008. When growth in 2008 was negative, we assumed the negative part as the below-ground dead biomass in 2008. Death rate was calculated as the percentage of dead biomass relative to total biomass. Root mass ratio (RMR) was calculated as the percentage of living below-ground biomass relative to the total amount of living biomass. $P$ uptake in 2007 was estimated by subtracting the average initial $\mathrm{P}$ content from the total amount of P content in 2007. P uptake in 2008 was estimated by subtracting the average $\mathrm{P}$ content of living below-ground biomass in 2007 for each treatment from the total $\mathrm{P}$ content in 2008. When $\mathrm{P}$ uptake in 2008 was negative, we assumed the negative part as loss from below-ground dead biomass in 2008. $\mathrm{P}$ loss rate was calculated as the percentage of $\mathrm{P}$ content in dead biomass relative to the total $\mathrm{P}$ content. Resorption rate of $P$ from senescing leaves was calculated for 2007 as the percentage difference in the $\mathrm{P}$ concentration between dead and living above-ground biomass, relative to that in living above-ground biomass. Plants that did not regenerate after the winter were excluded from the calculations for 2008. Plants that did not have any living biomass left in 2008 were excluded from the calculations of RMR.

\section{Statistical analysis}

The effects of the nutrient supply level, N:P supply ratios, species, and their interactions (all fixed factors) on various plant responses (growth, death rate, aboveground death rate, below-ground death rate, P uptake, P loss, N uptake, N loss in 2007 and 2008, and leaf resorption rate of $\mathrm{P}$ and $\mathrm{N}$ in 2007) were tested with a three-way ANOVA. Note that some of these plant response variables are autocorrelated because nutrient flows are related biomass flows; there were correlations among growth, $\mathrm{P}$ uptake, and $\mathrm{N}$ uptake, as well as among death rate, above-ground death rate, belowground death rate, $\mathrm{P}$ loss, and $\mathrm{N}$ loss. All variables except those expressed as percentages were log transformed or square root transformed to obtain normal distributions of the residuals. For the leaf resorption rate, three-way interaction was omitted, because we aggregated replicas of some treatments for $\mathrm{N}$ and $\mathrm{P}$ determination and therefore used average values of each treatment for each species in the ANOVA. L. flos-cuculi was excluded from ANOVA tests for 2008, as its regeneration rate in 2008 was very low $(6 \%)$. The factors that showed a significant effect in ANOVA were compared by a multiple comparison test, the Games-Howell test (Sokal and Rohlf 1995). We also tested the difference in growth and death rate between N:P supply ratios within each nutrient supply level (Games-Howell test) as well as between nutrient supply levels within each N:P supply ratio (Mann-Whitney $U$ test). Additionally, differences in death rates between 2007 and 2008 were analyzed by the $U$ test.

Relationships between death rate and biomass concentrations (N, P, and N:P) were tested by Spearman's correlation analysis. To check whether the treatment and species effects had influenced the relationships, we repeated the correlation analyses with corrected variables (i.e., after dividing their values by the average values of the treatment for each species).

\section{Results}

Effects of $\mathrm{N}$ and $\mathrm{P}$ supply on plant growth

The average plant growth across all species was significantly influenced by the nutrient supply level and N:P supply ratio in both years (Table 2). In 2007, growth was higher at the high supply level for all N:P ratios $(p<0.05)$. Per supply level, the intermediate $\mathrm{N}: \mathrm{P}$ supply ratio resulted in the highest growth. In 2008, average growth was higher at the 
high supply level $(p<0.001$, except for N:P supply ratio 135). At the high supply level, the low and intermediate N:P supply ratio resulted in high growth; at the low supply level, in contrast, the low

Table 2 Effects of species (Sp), nutrient supply levels (L), and $\mathrm{N}: \mathrm{P}$ supply ratios (NP) and their interactions on eight plant responses in 2007 and 2008. $\mathrm{F}$ values and $\mathrm{P}$ values $(* * * p<$ $0.001 ; * * p<0.01 ; * p<0.05)$ determined by 3 -way ANOVA, as
$\mathrm{N}: \mathrm{P}$ supply ratio yielded the highest growth. The ANOVA confirms that $\mathrm{N}: \mathrm{P}$ ratio affected plant growth differently per supply level in 2008 ( $p<$ 0.001 ). However, for both supply levels, growth was

well as treatment means (over all species) \pm SE for nutrient supply levels and N:P supply ratios, are shown. The results of multiple comparison among six treatments are shown with alphabets

$\begin{array}{llllllll}\begin{array}{l}\text { Growth } \\ (\mathrm{mg})\end{array} & \begin{array}{l}\text { Death } \\ (\%)\end{array} & \begin{array}{l}\text { Death above } \\ \text { ground }(\%)\end{array} & \begin{array}{l}\text { Death below } \\ \text { ground }(\%)\end{array} & \begin{array}{l}\text { P uptake } \\ (\mathrm{mg})\end{array} & \begin{array}{l}\text { P loss } \\ (\%)\end{array} & \begin{array}{l}\mathrm{N} \text { uptake } \\ (\mathrm{mg})\end{array} & \begin{array}{l}\mathrm{N} \text { loss } \\ (\%)\end{array}\end{array}$

\section{7}

ANOVA results

\begin{tabular}{|c|c|c|c|c|c|c|c|c|c|}
\hline Species & 7 & $88.0 * * *$ & $21.0 * * *$ & $28.6 * * *$ & $28.8 * * *$ & $79.8 * * *$ & $18.1 * * *$ & $97.1 * * *$ & $26.5 * * *$ \\
\hline Level & 1 & $131.4 * * *$ & $49.1 * * *$ & $88.5^{* * *}$ & 0.2 & $608.5 * * *$ & $68.9^{* * *}$ & $440.0 * * *$ & $77.6^{* * *}$ \\
\hline $\mathrm{N}: \mathrm{P}$ ratio & 2 & $12.2 * * *$ & $88.9^{* * *}$ & $81.2 * * *$ & 0.6 & $730.2 * * *$ & $46.0 * * *$ & $25.3 * * *$ & $75.3 * * *$ \\
\hline Sp x L & 7 & $4.0 * * *$ & $6.4 * * *$ & $6.4 * * *$ & 1.4 & $3.6^{* *}$ & $6.3 * * *$ & $3.3 * *$ & $5.5 * * *$ \\
\hline Sp $\times$ NP & 14 & $3.4 * * *$ & $4.5^{* * *}$ & $5.9 * * *$ & 1.1 & $7.0^{* * *}$ & $4.7 * * *$ & $10.7 * * *$ & $4.6 * * *$ \\
\hline L x NP & 2 & $4.2 *$ & 1.1 & 2.5 & 1.4 & $34.5 * * *$ & $3.4^{*}$ & $6.6^{* *}$ & 1.5 \\
\hline SpxLxNP & 14 & 0.6 & $2.3^{* *}$ & $2.4 * *$ & 1.3 & $1.8^{*}$ & $2.6 * * *$ & 1.1 & $3.2 * * *$ \\
\hline Error & 192 & & & & & & & & \\
\hline \multicolumn{10}{|c|}{ Treatment means \pm SE } \\
\hline Low \& N:P=1.7 & & $676 \pm 53^{\mathrm{d}}$ & $6.6 \pm 0.9^{\mathrm{d}}$ & $15.1 \pm 2.0^{\mathrm{d}}$ & $0.8 \pm 0.2^{\mathrm{a}}$ & $0.96 \pm 0.07^{\mathrm{b}}$ & $3.3 \pm 0.6^{\mathrm{b}}$ & $4.3 \pm 0.2^{\mathrm{e}}$ & $5.6 \pm 0.9^{\mathrm{c}}$ \\
\hline 15 & & $779 \pm 77^{\mathrm{c}}$ & $8.6 \pm 1.0^{\mathrm{c}}$ & $17.5 \pm 2.1^{\mathrm{c}}$ & $1.7 \pm 0.5^{\mathrm{a}}$ & $0.27 \pm 0.04^{\mathrm{c}}$ & $3.8 \pm 0.6^{\mathrm{b}}$ & $7.4 \pm 0.7^{\mathrm{b}}$ & $4.1 \pm 0.5^{\mathrm{d}}$ \\
\hline 135 & & $685 \pm 73^{\mathrm{d}}$ & $15.0 \pm 0.9^{\mathrm{a}}$ & $29.5 \pm 2.0^{\mathrm{a}}$ & $1.4 \pm 0.3^{\mathrm{a}}$ & $0.07 \pm 0.02^{\mathrm{d}}$ & $7.1 \pm 0.9^{\mathrm{a}}$ & $7.9 \pm 0.9^{\mathrm{d}}$ & $8.9 \pm 0.8^{\mathrm{a}}$ \\
\hline High \& N:P=1.7 & & $1190 \pm 81^{\mathrm{a}}$ & $4.6 \pm 1.0^{\mathrm{d}}$ & $8.0 \pm 1.5^{\mathrm{f}}$ & $0.9 \pm 0.2^{\mathrm{a}}$ & $2.86 \pm 0.23^{\mathrm{a}}$ & $2.3 \pm 0.5^{\mathrm{b}}$ & $12.4 \pm 0.7^{\mathrm{c}}$ & $2.7 \pm 0.5^{\mathrm{e}}$ \\
\hline 15 & & $1427 \pm 126^{\mathrm{a}}$ & $5.8 \pm 1.1^{\mathrm{d}}$ & $9.5 \pm 1.7^{\mathrm{e}}$ & $0.9 \pm 0.2^{\mathrm{a}}$ & $1.07 \pm 0.09^{\mathrm{b}}$ & $2.3 \pm 0.7^{\mathrm{b}}$ & $22.4 \pm 1.7^{\mathrm{a}}$ & $3.2 \pm 0.7^{\mathrm{e}}$ \\
\hline 135 & & $976 \pm 93^{\mathrm{b}}$ & $11.6 \pm 1.1^{\mathrm{b}}$ & $20.9 \pm 2.2^{\mathrm{b}}$ & $0.9 \pm 0.2^{\mathrm{a}}$ & $0.26 \pm 0.03^{\mathrm{c}}$ & $3.8 \pm 0.5^{\mathrm{b}}$ & $15.9 \pm 1.4^{\mathrm{b}}$ & $7.1 \pm 1.0^{\mathrm{b}}$ \\
\hline
\end{tabular}

2008

\section{ANOVA results}

\begin{tabular}{|c|c|c|c|c|c|c|c|c|c|}
\hline Species & 6 & $21.2 * * *$ & $45.9 * * *$ & $31.2 * * *$ & $58.4 * * *$ & $16.5^{* * *}$ & $62.1 * * *$ & $27.1 * * *$ & $82.4 * * *$ \\
\hline Level & 1 & $107.2 * * *$ & 2.2 & 0.0 & 0.1 & $83.2 * * *$ & 0.0 & $71.4 * * *$ & 0.1 \\
\hline $\mathrm{N}: \mathrm{P}$ ratio & 2 & $133.4 * * *$ & $51.8 * * *$ & $19.8^{* * *}$ & $49.2 * * *$ & $180.4 * * *$ & $67.2 * * *$ & $82.6^{* * *}$ & $61.5^{* * *}$ \\
\hline $\mathrm{Sp} \times \mathrm{L}$ & 6 & $4.0 * *$ & $3.3^{* *}$ & 1.5 & $5.0^{* * *}$ & $4.0 * *$ & $2.8^{*}$ & $2.3^{*}$ & $3.1 * *$ \\
\hline $\mathrm{Sp} \times \mathrm{NP}$ & 12 & $5.7 * * *$ & $3.3 * * *$ & 0.8 & $4.7 * * *$ & $5.6^{* * *}$ & $8.4 * * *$ & $7.2 * * *$ & $6.1 * * *$ \\
\hline$L \times N P$ & 2 & $36.4 * * *$ & $6.7 * *$ & $4.1^{*}$ & $4.9 * *$ & $19.4 * * *$ & $12.4 * * *$ & $21.3 * * *$ & $7.5 * *$ \\
\hline SpxLxNP & 12 & $2.4 * *$ & $6.4 * * *$ & 1.5 & $6.5^{* * *}$ & $2.6^{* *}$ & $6.0 * * *$ & $3.1 * *$ & $6.7 * * *$ \\
\hline Error & 173 & & & & & & & & \\
\hline \multicolumn{10}{|c|}{ Treatment means $\pm \mathrm{SE}$} \\
\hline Low \& N:P=1.7 & & $1437 \pm 151^{\mathrm{b}}$ & $17.5 \pm 2.6^{\mathrm{e}}$ & $24.6 \pm 2.9^{\mathrm{c}}$ & $15.1 \pm 2.9^{\mathrm{d}}$ & $1.16 \pm 0.11^{\mathrm{b}}$ & $14.8 \pm 2.6^{\mathrm{d}}$ & $6.6 \pm 0.5^{\mathrm{c}}$ & $21.1 \pm 2.7^{c}$ \\
\hline 15 & & $474 \pm 76^{\mathrm{c}}$ & $27.6 \pm 3.8^{\mathrm{d}}$ & $34.4 \pm 3.5^{\mathrm{b}}$ & $24.8 \pm 4.2^{\mathrm{d}}$ & $0.15 \pm 0.02^{\mathrm{c}}$ & $28.1 \pm 3.8^{\mathrm{d}}$ & $4.7 \pm 0.6^{\mathrm{d}}$ & $28.0 \pm 3.7^{\mathrm{c}}$ \\
\hline 135 & & $189 \pm 41^{\mathrm{e}}$ & $49.7 \pm 6.2^{\mathrm{a}}$ & $49.9 \pm 5.6^{\mathrm{a}}$ & $49.5 \pm 6.5^{\mathrm{b}}$ & $0.05 \pm 0.01^{\mathrm{e}}$ & $51.5 \pm 5.9^{\mathrm{b}}$ & $2.5 \pm 0.7^{\mathrm{e}}$ & $49.6 \pm 6.2^{\mathrm{a}}$ \\
\hline High \& N:P=1.7 & & $2483 \pm 262^{a}$ & $29.5 \pm 5.3^{\mathrm{c}}$ & $34.4 \pm 5.3^{\mathrm{b}}$ & $26.1 \pm 5.4^{\mathrm{c}}$ & $2.52 \pm 0.26^{\mathrm{a}}$ & $28.4 \pm 5.6^{\mathrm{c}}$ & $12.3 \pm 1.0^{\mathrm{b}}$ & $30.6 \pm 5.4^{\mathrm{b}}$ \\
\hline 15 & & $2798 \pm 203^{\mathrm{a}}$ & $23.3 \pm 4.2^{\mathrm{e}}$ & $25.7 \pm 5.0^{\mathrm{c}}$ & $21.5 \pm 4.3^{\mathrm{d}}$ & $1.09 \pm 0.08^{\mathrm{b}}$ & $21.4 \pm 4.7^{\mathrm{d}}$ & $22.8 \pm 1.5^{\mathrm{a}}$ & $23.3 \pm 4.6^{\mathrm{C}}$ \\
\hline 135 & & $378 \pm 787^{d}$ & $52.1 \pm 5.6^{\mathrm{b}}$ & $49.2 \pm 5.8^{\mathrm{a}}$ & $52.2 \pm 6.0^{\mathrm{a}}$ & $0.12 \pm 0.02^{\mathrm{d}}$ & $53.7 \pm 6.1^{\mathrm{a}}$ & $5.8 \pm 1.3^{\mathrm{d}}$ & $52.9 \pm 5.6^{\mathrm{a}}$ \\
\hline
\end{tabular}


significantly lower at the N:P supply ratio 135 than at the other ratios $(p<0.01)$.

Looking at the responses per plant species, the results revealed a large interspecific variation in growth in both years (Table 2). Note that, for species-specific effects, we have reported the results for the whole (Fig. 1). We did so because the year effects were similar for most species, with some minor deviation for a particular year (see Appendix 1 and 2). Although there was a significant interaction effect between species and N:P supply ratio in both years (Table 2), all species had the lowest total growth at N:P supply ratio 135 over two years (Fig. 1a).

Effects of $\mathrm{N}$ and $\mathrm{P}$ supply on plant death rate

In 2007 the average death rate of the whole biomass (below- and above-ground biomass together) across all plant species increased with an increasing $\mathrm{N}: \mathrm{P}$ supply ratio and a decreasing nutrient supply level (Table 2). Death of below-ground biomass was small, amounting to less than a few percent (Table 2). In 2008 the average death rate of the whole biomass was much higher than in 2007 for all six treatments $(p<$ 0.001). In 2008, the death rate rose with an increasing $\mathrm{N}: \mathrm{P}$ supply ratio independent of the nutrient supply level (Table 2), and the death rate of the belowground biomass was much higher than in 2007 (Table 2). The death rate of the whole biomass in 2008 was particularly high at an N:P supply ratio of 135 , where the death rate did not differ significantly between low and high nutrient levels $(p=0.35)$. Although interaction effects between nutrient supply level and N:P supply ratio were significant for the year 2008, the trend remained that for both supply levels the death rate rose as the N:P ratio increased. There was one exception to this at the high nutrient
Fig. 1 Species difference in a) growth, b) death rate, c) $\mathrm{P}$ uptake, and d) P loss over two years (15 weeks of fertilization in 2007, 14 weeks of fertilization in 2008 , plus the winter in between) in response to different N:P supply ratios. See Materials and Methods for the definition of each of the variables. Means of high and low nutrient supply levels combined are shown. For growth and $\mathrm{P}$ uptake, the sums of SE for 2007 and SE for 2008 are shown as an indicator of their variability over 2 years a)

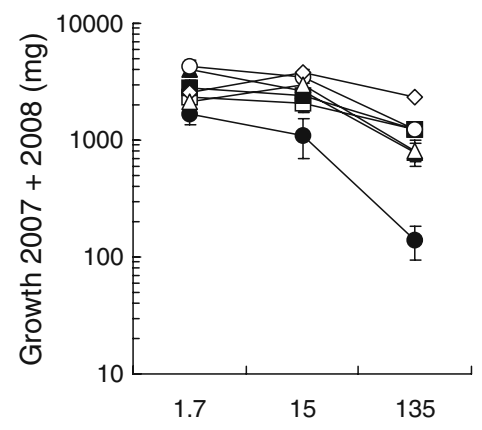

c)

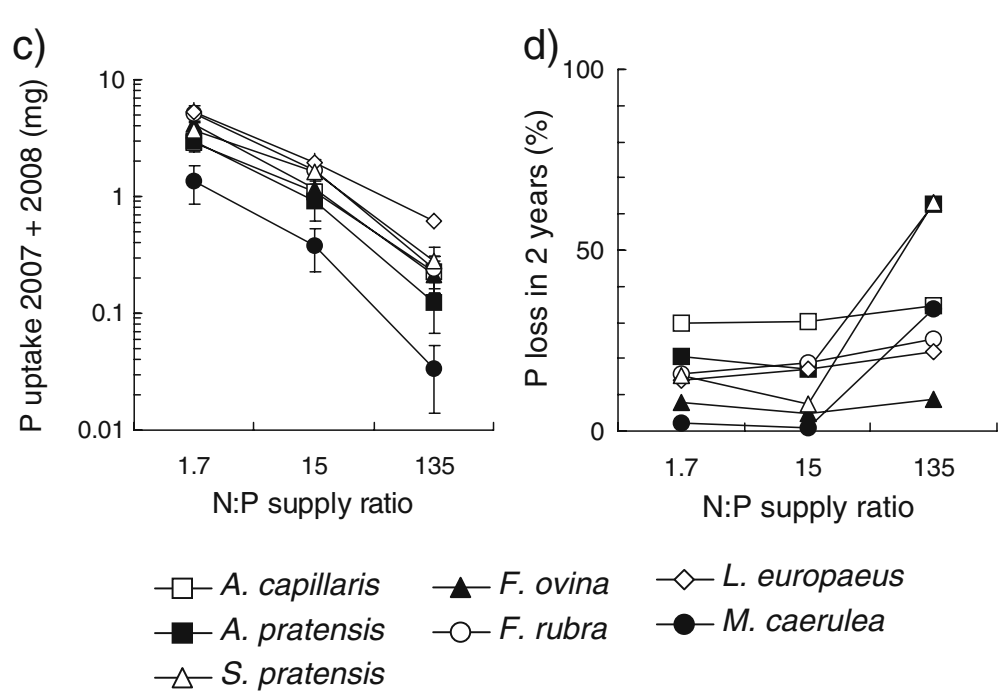

d)
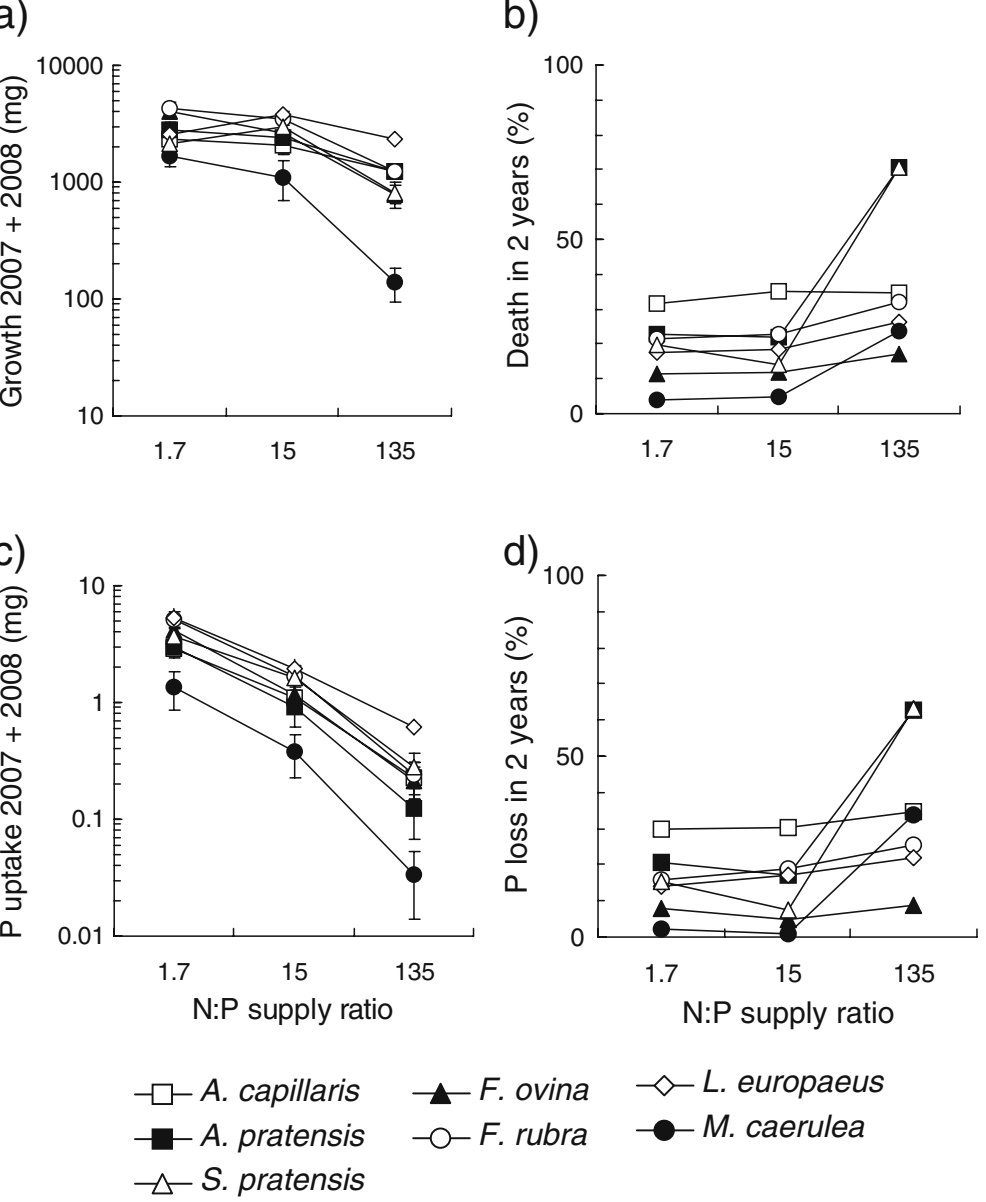
level, where the death rate was slightly higher for the intermediate than for the high $\mathrm{N}: \mathrm{P}$ ratio.

Correlation analysis showed that the death rate of the whole biomass was negatively related to both concentrations of $\mathrm{N}$ and $\mathrm{P}$ in plant biomass, but more strongly to the $\mathrm{P}(r=-0.42, p<0.001)$ than to the $\mathrm{N}$ $(r=-0.17, p<0.001)$ concentration. These negative correlations were also found when the treatment and species effects were corrected $(r=-0.49$ and $p<0.001$ for $\mathrm{P}$ concentration; $r=-0.57$ and $p<0.001$ for $\mathrm{N}$ concentration). In addition, the plant death rate was positively correlated with the biomass $\mathrm{N}: \mathrm{P}$ ratio $(r=0.30, p<0.001)$.

There was a high interspecific variation in the death rates, especially in 2008 (Table 2; see also Appendix 1b, 2b). In both years, species responded differently to N:P supply ratios (Table 2). The total death rate over two years at an N:P ratio of 135 was the lowest for $F$. ovina, followed by M. caerulea and L. europaeus (Fig. 2b).

Effects of $\mathrm{N}$ and $\mathrm{P}$ supply on nutrient uptake

We observed somewhat different patterns in the $\mathrm{P}$ and $\mathrm{N}$ uptake of plants in response to $\mathrm{N}: \mathrm{P}$ supply ratio than those in growth, despite that the uptake rates were autocorrelated with growth. The $\mathrm{P}$ uptake decreased with a rising N:P supply ratio in both years, while the $\mathrm{N}$ uptake differed from one year to the next. The $\mathrm{N}$ uptake was lowest at the low $\mathrm{N}: \mathrm{P}$ ratio in 2007 but lowest at the high $\mathrm{N}: \mathrm{P}$ ratio in 2008 (Table 2). The proportion of $\mathrm{N}$ and $\mathrm{P}$ taken up from the supplied $\mathrm{N}$ and $\mathrm{P}$ in two years decreased with an increasing N:P supply ratio. The $\mathrm{N}$ uptake was $92 \pm$ $9 \%$ for $\mathrm{N}: \mathrm{P}$ supply ratio $1.7,41 \pm 5 \%$ for $\mathrm{N}: \mathrm{P} 15$, and $8 \pm 2 \%$ for N:P 135 . The P uptake was $31 \pm 4 \%$ for $\mathrm{N}: \mathrm{P}$ $1.7,25 \pm 4$ for $\mathrm{N}: \mathrm{P} 15$, and $15 \pm 4 \%$ for N:P 135 . This means that the plants that were grown at the high $\mathrm{N}: \mathrm{P}$ supply ratio not only received less $\mathrm{P}$ but also took up smaller percentages of the P supplied. With an N:P supply ratio of 135 , the $\mathrm{P}$ uptake was especially small in 2008 (18.5\% of total P uptake). At this N:P supply ratio, the initial content of $\mathrm{P}$ from the pre-fertilization period consisted of a large proportion $(38.8 \%)$ of the total $\mathrm{P}$ content.

Total P uptake over two years largely differed among species at the N:P supply ratio of 135 (Fig. 1c). L. europaeus took up $82.9 \%$ of the supplied $\mathrm{P}$ whereas $M$. caerulea took up only $4.1 \%$.

\section{Effects of $\mathrm{N}$ and $\mathrm{P}$ supply on nutrient retention}

Similar to the plant death rates (and partly due to the autocorrelation), the losses of $\mathrm{N}$ and $\mathrm{P}$ increased with an increasing N:P supply ratio in both years, while they were not significantly influenced by the nutrient supply level in 2008 (Table 2). The P loss over two years became larger as the $\mathrm{N}: \mathrm{P}$ ratio increased (Fig. 2a, see dotted lines): the loss amounted to $18.1 \%$ for $\mathrm{N}: \mathrm{P}$ supply ratio $1.7,20.2 \%$ for $\mathrm{N}: \mathrm{P} 15$, and $37.1 \%$ for $\mathrm{N}: \mathrm{P} 135$. Of the total P loss, the loss from below-ground dead biomass in 2008 was larger than that from above-ground biomass. Moreover, that loss from below ground increased along with the $\mathrm{N}: \mathrm{P}$ a)

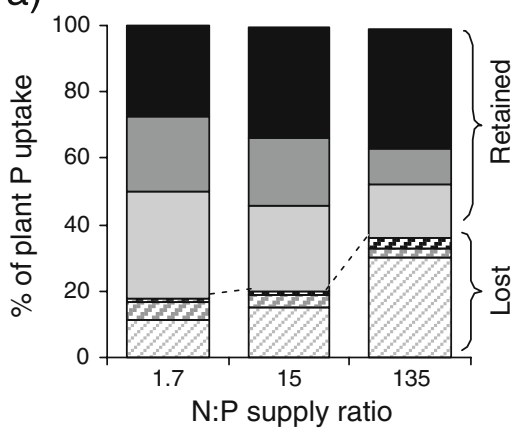

Fig. 2 Loss or retention of $\mathrm{P}$ (a) and $\mathrm{N}$ (b) of plants grown with different N:P supply ratios, shown as percentages of total uptake of $\mathrm{P}$ or $\mathrm{N}$ in two years. Means of high and low supply level across seven species (except L. flos-cuculi) are shown. Each compartment represents a part of the biomass (above-

b)

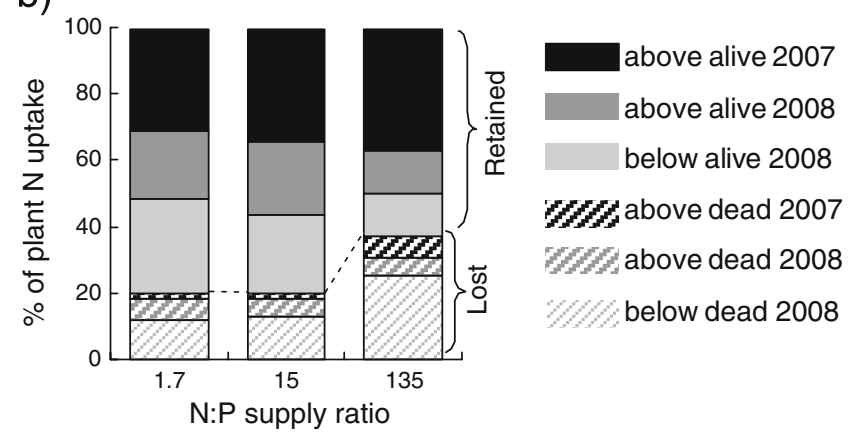

ground alive, below-ground alive, above-ground dead, belowground dead) of each year. Below-ground dead of 2007 was omitted because it consisted of less than $1 \%$. Dotted lines show the distinction between nutrient lost from plants and nutrient retained in plants 
ratio: the loss was $61.0 \%$ for $\mathrm{N}: \mathrm{P}$ supply ratio 1.7 , $74.0 \%$ for $\mathrm{N}: \mathrm{P} 15$, and $81.2 \%$ for $\mathrm{N}: \mathrm{P} 135$. The same patterns were observed for $\mathrm{N}$ loss. That is, we found an increasing $\mathrm{N}$ loss and increasing proportion of $\mathrm{N}$ loss from below-ground dead biomass in 2008 as the N:P supply ratio increased (Fig. 2b).

The total $\mathrm{P}$ loss over two years largely differed among species, especially at N:P supply ratio 135 . F. ovina had the lowest $\mathrm{P}$ loss rate whereas $A$. pratensis and $S$. pratensis had a higher $\mathrm{P}$ loss rate than the others (Table 2, Fig. 1d). For all species, P was lost mainly from below-ground dead biomass in 2008 . The contribution of $\mathrm{P}$ loss from below-ground biomass to the total $\mathrm{P}$ loss in 2008 was especially large for S. pratensis (93\%), M. caerulea (92\%), and A. pratensis $(87 \%)$.

The $\mathrm{N}$ resorption rate from senescing leaves in 2007 was influenced by the N:P supply ratio $\left(F_{2,14}=\right.$ $14.7, p<0.01)$. The $\mathrm{N}$ resorption rate was higher for an N:P supply ratio of 15 than of $135(p<0.05)$. The $\mathrm{P}$ resorption rate was not influenced by the N:P supply ratio $\left(F_{2,14}=1.1, p=0.35\right)$. Species variation in the resorption rates was statistically significant for both $\mathrm{N}$ resorption $\left(F_{7,14}=57.3, p<0.001\right)$ and $\mathrm{P}$ resorption $\left(F_{7,14}=11.4, p<0.001\right)$. M. caerulea and $F$. ovina had the highest and the second highest resorption rates for both $\mathrm{N}$ and $\mathrm{P}$.

\section{Discussion}

General trends in $\mathrm{N}$ and $\mathrm{P}$ supply effects on plant growth and nutrient economy

The present study shows that the availability of $\mathrm{N}$ and $\mathrm{P}$ influences plant growth and nutrient economy in terms of supply levels as well as of the N:P supply ratio. Moreover, the effects of $\mathrm{N}: \mathrm{P}$ supply ratio are shown to change over time. Our results regarding plant biomass productivity are comparable to those of previous similar experiments (Güsewell 2005a,c). Notably, in the first year, both high and low N:P supply ratios resulted in a relatively low biomass compared to the intermediate $\mathrm{N}: \mathrm{P}$ supply ratio, whereas in the second year it was especially the high $\mathrm{N}$ :P supply ratio that resulted in a low biomass. As the present experiment traced the major nutrient flows to and from plants over a period of two years, we were able to relate the negative effects of high $\mathrm{N}: \mathrm{P}$ supply ratio, especially in the long term, to high nutrient losses via the death of roots.

The high death rate in the second year was influenced by a high N:P supply ratio, but not by the nutrient supply level alone. Our experimental design included, besides the different N:P supply ratios and nutrient supply levels, some identical supplies of $\mathrm{N}$ and of $\mathrm{P}$. By comparing these identical supplies we could see that the increased death rate at the high $\mathrm{N}: \mathrm{P}$ ratio was due to a relative scarcity of $\mathrm{P}$ to $\mathrm{N}$, rather than to $\mathrm{N}$ toxicity or $\mathrm{P}$ limitation per se. First, the two treatments with the same high $\mathrm{N}$ supply but at a contrasting $\mathrm{P}$ supply (i.e., High \& $\mathrm{N}: \mathrm{P}=15$ and Low \& $\mathrm{N}: \mathrm{P}=135$ ) showed that a high $\mathrm{N}$ supply led to high death rates only when the $\mathrm{P}$ supply was relatively low. This implies that $\mathrm{N}$ toxicity is not the main cause of high N:P ratio effects. Moreover, the two treatments with the same low $\mathrm{P}$ supply but a contrasting $\mathrm{N}$ supply (i.e., High \& $\mathrm{N}: \mathrm{P}=135$ and Low $\& \mathrm{~N}: \mathrm{P}=15$ ) showed that a low $\mathrm{P}$ supply led to a high death rate only when the $\mathrm{N}$ supply was relatively high. This implies that $\mathrm{P}$ limitation per se is not the main cause either. Together, these results suggest an independent effect of N:P supply ratios on plant death rate apart from the effects of $\mathrm{N}$ or $\mathrm{P}$ supply levels.

The effects of N:P supply ratio on plant death rate might be explained by differences in the way plants are able to adapt the $\mathrm{N}$ and $\mathrm{P}$ concentration in biomass to their environment (Aerts and Chapin 2000; Güsewell and Koerselman 2002). We found that the plants adjusted their $\mathrm{P}$ concentrations more flexibly than their $\mathrm{N}$ concentration. That is, the $\mathrm{P}$ concentration in living biomass decreased considerably as the N:P supply ratio increased (82\% decrease from N:P supply ratio 1.7 to 135), whereas the $\mathrm{N}$ concentration decreased only slightly as the N:P supply ratio decreased (26\% decrease from N:P supply ratio 135 to 1.7 ) in 2007 (see Appendix 3 for the average nutrient concentrations of each treatment for each part of the biomass). Considering that the reduction of $\mathrm{P}$ concentration below a minimum requirement will cause senescence of tissues (Batten and Wardlaw 1987), higher flexibility of $\mathrm{P}$ than $\mathrm{N}$ concentration in biomass could explain the increased death rate at high $\mathrm{N}: \mathrm{P}$ supply ratios, but not at low $\mathrm{N}: \mathrm{P}$ supply ratios. The importance of $\mathrm{P}$ concentration to the death rate is also underpinned by our observation that plant death rates were more strongly correlated to $\mathrm{P}$ than to $\mathrm{N}$ concentration in biomass. 
In addition, poor $\mathrm{P}$ uptake (in terms of both the absolute amount and the percentage relative to supplied $\mathrm{P}$ ) at a high N:P supply ratio could be another reason why plants kept such low P concentrations. Our additional laboratory experiment showed that part of the supplied P could be adsorbed to the substrate (ca. $30 \%$ of the orthophosphate was adsorbed to the quartz sand within a week when the $\mathrm{P}$ concentration in the solution was comparable to that in our Low, $\mathrm{N}: \mathrm{P}=15$ treatment). We are also aware of a possible underestimation of nutrient uptake because of our discrete (once a year) rather than continuous measurements of the nutrient content in biomass. With this method, we were unable to trace nutrient losses via root exudates, which are often stimulated by P deficiency (Vance et al. 2003). These artefacts of our experiment, however, are still not enough to explain the extremely low percentage of $\mathrm{P}$ taken up by plants (15\%) at a high $\mathrm{N}: \mathrm{P}$ ratio. Although a high rate of $\mathrm{P}$ uptake by $\mathrm{P}$-deficient plants is commonly observed in short-term experiments (e.g. Güsewell 2005c; Shaver and Melillo 1984), another two-year growth experiment also revealed poor nutrient recovery (i.e., percentage of nutrient accumulated in plants relative to its supply) under conditions of P- rather than N-limitation (Güsewell 2005a). Furthermore, Craine and Jackson (2009) reported a trend whereby plants grown on low-P soil do not increase biomass upon $\mathrm{P}$ fertilization alone, whereas those on low-N soil do increase biomass upon $\mathrm{N}$ fertilization, indicating a stronger inhibition of nutrient acquisition under $\mathrm{P}$ rather than $\mathrm{N}$ stress.

In reality, however, drastic nutrient losses and poor $\mathrm{P}$ uptake at high N:P supply ratios, as those observed in our experiment, are less likely to happen. Under natural conditions, unlike in our experiment, there exist various forms of $\mathrm{P}$ bound to soil that plants can effectively take up by several mechanisms such as excretion of root exudates (Lambers et al. 2006; Raghothama and Karthikeyan 2005; Vance et al. 2003). A low mycorrhizal infection rate on the plant roots in our experiment (on average 14\% in 2007) compared to their field status (Weishampel and Bedford 2006) may have also led to the observed low P uptake by plants. Still, rapid increase of atmospheric nitrogen deposition (Galloway 1995; Holland et al. 1999) could invoke a strong (relative) $P$ limitation in plants and influence the nutrient budget of the ecosystems by enhancing nutrient loss from the plant rhizosphere.
Interspecific difference in response to high $\mathrm{N}: \mathrm{P}$ supply ratios

By including eight different grassland species in the experiment, we were able to identify possible mechanisms that cause species-specific responses to varying $\mathrm{N}: \mathrm{P}$ supply ratios. Species variation in impaired $\mathrm{P}$ uptake and increased P loss in the second year, which were the main negative effects of the high N:P supply ratio (see previous section), seemed to determine the differences in the growth of the species. The top three fastest growing species in the second year at the high $\mathrm{N}$ : P supply ratio (L. europaeus, F. ovina, and F. rubra in rank order) suffered less from $P$ losses than the other species, and the fastest growing species (L. europaeus) had the highest $\mathrm{P}$ uptake compared to all other species.

Interspecific differences in $P$ loss could be caused by several factors. First, species that had poor P uptake inevitably had a lowered $\mathrm{P}$ concentration, which resulted in high death rates. Also the sensitivity of death rate to low $\mathrm{P}$ concentration seemed species specific: $M$. caerulea and $F$. ovina had relatively low death rates even at low $\mathrm{P}$ concentrations, possibly due to interspecific differences in optimum nutrient concentrations in biomass (Agren 2008). Secondly, variation in leaf resorption rates could have influenced the species differences in $\mathrm{P}$ losses. The higher resorption rate by $M$. caerulea and $F$. ovina counteracted the negative effects of increased death rates. Such interspecific differences in resorption efficiency are also reported by other studies (Aerts and Chapin 2000; Güsewell 2005b). Thirdly, variation in root mass ratio (RMR) (results not shown) could also have contributed to the species difference in P loss. Since loss from belowground dead biomass was the major path of P loss, higher allocation to roots may ultimately have resulted in a higher loss rate. The much lower nutrient resorption rate from senescing roots compared to that from leaves (Gordon and Jackson 2000; this experiment) may have accelerated this effect. Indeed, the contribution of below-ground P loss to total P loss was very high for species that had high RMR (M. caerulea, $S$. pratensis, and A. pratensis).

Contrary to our hypothesis (4), those species that commonly occur in P-limited grasslands, i.e., $M$. caerulea and $S$. pratensis, did not perform better at a high N:P supply ratio than the other species. They actually had the worst performance in terms of $\mathrm{P}$ uptake (M. caerulea) or P loss (S. pratensis). A study 
on phosphatase activity with the same set of species (Fujita et al. 2010) shows that M. caerulea and $S$. pratensis have efficient phosphatase activity (i.e., high phosphatase activity per unit of biomass). Because phosphatase excretion requires large quantities of $\mathrm{N}$ (Treseder and Vitousek 2001), the intensive investment of these two species in phosphatase seemed to turn out to be 'wasted' in our experimental setting, as we did not supply organic $\mathrm{P}$, the $\mathrm{P}$ form that phosphatase mobilizes. In contrast, L. europaeus, which had the highest $\mathrm{P}$ uptake in our experiment, has poor phosphatase activity (Fujita et al. 2010). L. europaeus has less dependency on phosphatase but may have other traits to promote $\mathrm{P}$ acquisition, e.g., nutrient carrier enzyme in roots, which might have worked advantageously in our experiment.

\section{Conclusion}

We have quantitatively shown that severe $\mathrm{P}$ limitation (i.e., low availability of $\mathrm{P}$ relative to $\mathrm{N}$ ) causes high root death and thus results in poor nutrient retention in plants. These results indicate that unbalanced anthropogenic impacts on $\mathrm{N}$ and $\mathrm{P}$ availability to grassland ecosystems will influence their nutrient budget in the long term, for instance by stimulating nutrient loss from the rhizosphere under a high level of $\mathrm{N}$ eutrophication relative to $\mathrm{P}$ eutrophication. This might consequently alter the plant community structure by favoring plants with an adequate growth strategy that circumvents unbalanced N:P availability, e.g., an efficient P uptake or an enhanced $\mathrm{P}$ retention under conditions of $\mathrm{P}$ limitation. To further understand the significance and consequence of the increased root death under $\mathrm{P}$ stress, future research needs to examine the underlying physiological mechanisms that trigger the high death rate. Future studies should also test the effects of $\mathrm{P}$ stress in experimental conditions that mimic the field nutrient status in soil more realistically (i.e., by including various forms of phosphorus).

Acknowledgements The authors are grateful to N. Hölzel and D. Ertsen for sharing their field distribution data of plants and to J.J. Vierstra, C. Savage, and J.M. Diaz Tocados for their help in the greenhouse experiment. Y.F. is funded by the Utrecht Center of Geoscience.

Open Access This article is distributed under the terms of the Creative Commons Attribution Noncommercial License which permits any noncommercial use, distribution, and reproduction in any medium, provided the original author(s) and source are credited. 


\section{Appendix 1}

Fig. 3 Species differences in growth (a), death rate (b), P uptake (c), P loss (d), and root mass ratio (e) in 2007 in response to different $\mathrm{N}: \mathrm{P}$ ratios for high (left) and low (right) nutrient supply levels. Means and SE are shown
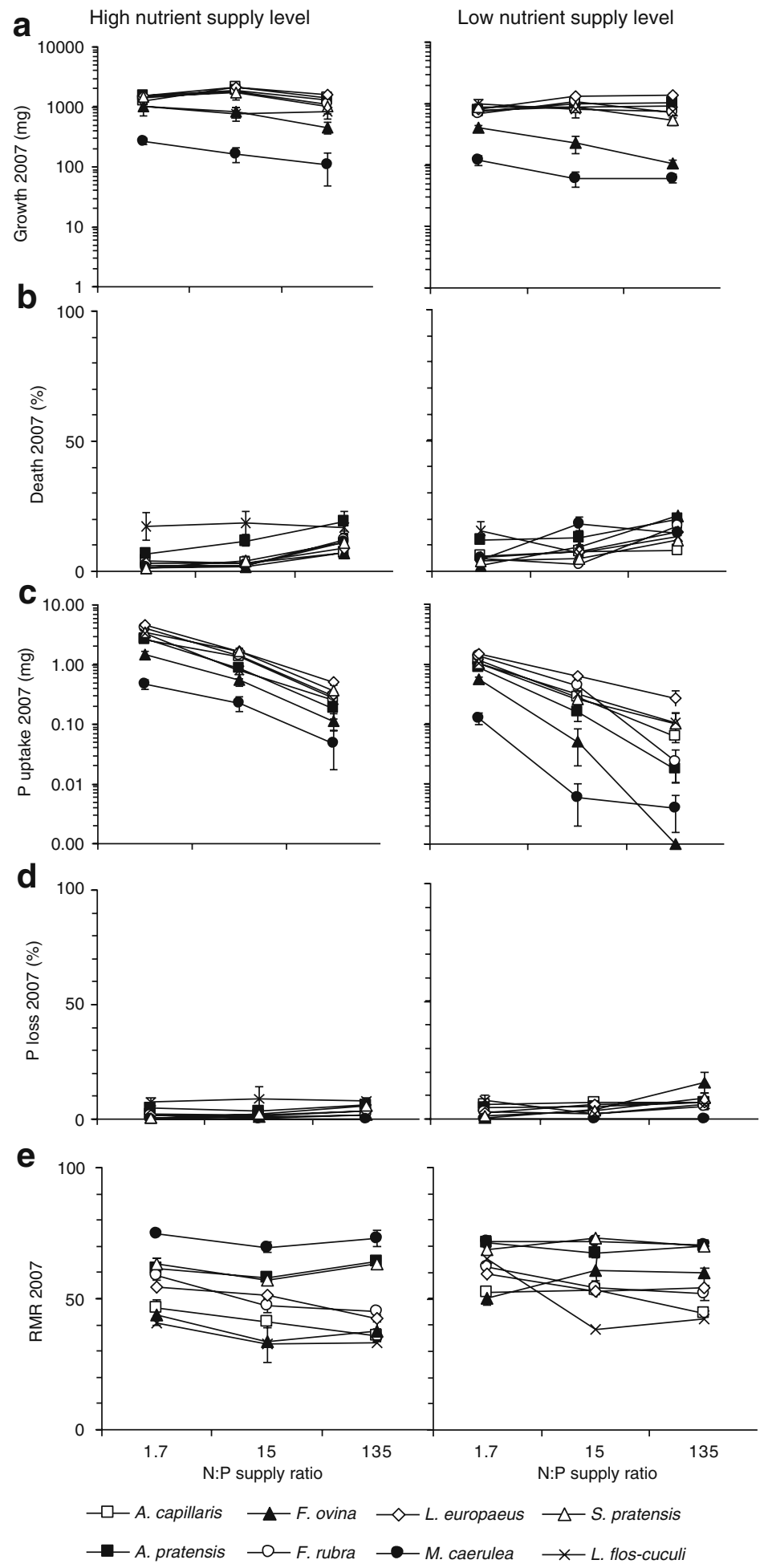


\section{Appendix 2}

Fig. 4 Species differences in growth (a), death rate (b), $P$ uptake (c), P loss (d), and root mass ratio (e) in 2008 in response to different $\mathrm{N}: \mathrm{P}$ ratios for high (left) and low (right) nutrient supply levels. Treatments that had fewer than three regenerated pots were omitted. Means and SE are shown
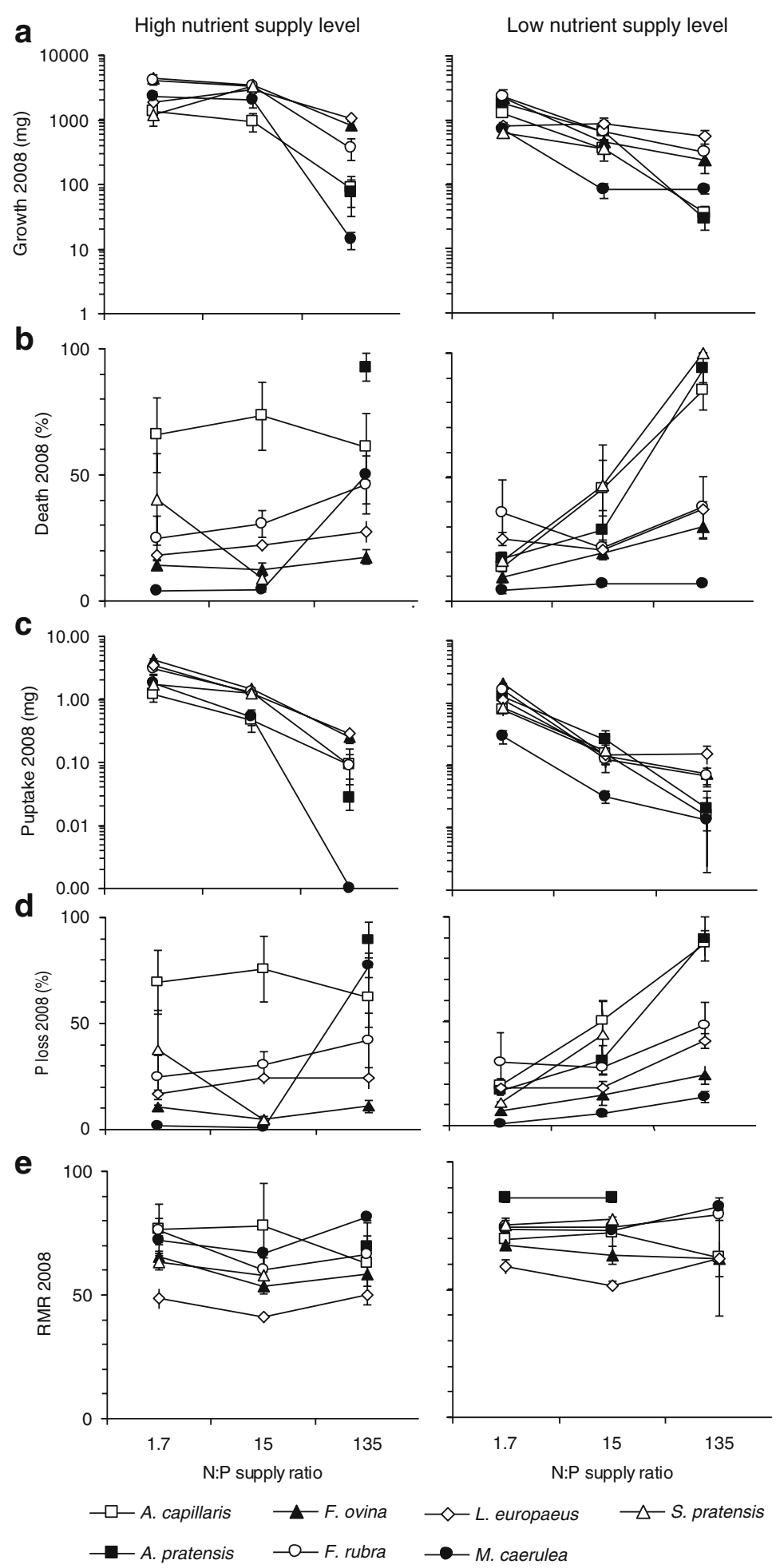


\section{Appendix 3}

Table 3 Concentrations of $\mathrm{N}$ and $\mathrm{P}$ in plant biomass. Treatment means and SE $(\mathrm{mg} / \mathrm{g})$ are shown for alive and dead parts for below-ground and above-ground biomass. Plant individuals which did not regenerate in the second year were excluded from the analysis. Number of samples measured is shown in brackets. Note that not all individuals had a complete set of these four parts each year. Furthermore, when a sample was too small, it was combined with other samples of the same treatment for determining nutrient concentrations (see Methods). The treatments marked with an asterisk contain such combined samples. Because of this methodological constraint, multiple comparisons among treatments were not conducted

\begin{tabular}{|c|c|c|c|c|c|c|c|c|}
\hline & $\begin{array}{l}\mathrm{P} \text { above- } \\
\text { ground alive }\end{array}$ & $\begin{array}{l}\mathrm{P} \text { below- } \\
\text { ground alive }\end{array}$ & $\begin{array}{l}\text { P above- } \\
\text { ground dead }\end{array}$ & $\begin{array}{l}\text { P below- } \\
\text { ground dead }\end{array}$ & $\begin{array}{l}\mathrm{N} \text { above- } \\
\text { ground alive }\end{array}$ & $\begin{array}{l}\mathrm{N} \text { below- } \\
\text { ground alive }\end{array}$ & $\begin{array}{l}\mathrm{N} \text { above- } \\
\text { ground dead }\end{array}$ & $\begin{array}{l}\mathrm{N} \text { below- } \\
\text { ground dead }\end{array}$ \\
\hline \multicolumn{9}{|l|}{2007} \\
\hline Low \& N:P=1.7 & $2.19 \pm 0.12\left(40^{*}\right)$ & $2.19 \pm 0.12(40)$ & $0.70 \pm 0.11\left(40^{*}\right)$ & $0.68 \pm 0.09(23 *)$ & $14.0 \pm 0.7\left(40^{*}\right)$ & $6.7 \pm 0.5(40)$ & $5.4 \pm 0.6\left(40^{*}\right)$ & $10.0 \pm 1.2(23 *)$ \\
\hline 15 & $0.53 \pm 0.03\left(40^{*}\right)$ & $0.53 \pm 0.03\left(40^{*}\right)$ & $0.21 \pm 0.03(40 *)$ & $0.53 \pm 0.07\left(25^{*}\right)$ & $14.8 \pm 0.9\left(40^{*}\right)$ & $9.2 \pm 0.4(40 *)$ & $5.6 \pm 0.4\left(40^{*}\right)$ & $8.9 \pm 1.0\left(25^{*}\right)$ \\
\hline 135 & $0.28 \pm 0.02(40 *)$ & $0.28 \pm 0.02\left(40^{*}\right)$ & $0.10 \pm 0.01\left(40^{*}\right)$ & $0.44 \pm 0.06\left(26^{*}\right)$ & $15.0 \pm 0.8\left(40^{*}\right)$ & $11.2 \pm 0.4\left(40^{*}\right)$ & $7.4 \pm 0.6\left(40^{*}\right)$ & $8.5 \pm 1.0\left(26^{*}\right)$ \\
\hline High \& N:P=1.7 & $2.98 \pm 0.20\left(40^{*}\right)$ & $2.98 \pm 0.20(40)$ & $1.17 \pm 0.14\left(40^{*}\right)$ & $0.72 \pm 0.12(28 *)$ & $16.9 \pm 0.7\left(40^{*}\right)$ & $8.6 \pm 0.6(40)$ & $5.8 \pm 0.6\left(40^{*}\right)$ & $9.5 \pm 1.1\left(28^{*}\right)$ \\
\hline 15 & $1.15 \pm 0.07\left(40^{*}\right)$ & $1.15 \pm 0.07(40)$ & $0.22 \pm 0.03(39 *)$ & $0.81 \pm 0.07\left(25^{*}\right)$ & $22.1 \pm 0.9\left(40^{*}\right)$ & $13.2 \pm 0.7(40)$ & $6.5 \pm 0.7\left(39^{*}\right)$ & $12.6 \pm 0.4(25 *)$ \\
\hline 135 & $0.46 \pm 0.02\left(40^{*}\right)$ & $0.46 \pm 0.02\left(40^{*}\right)$ & $0.12 \pm 0.01(40 *)$ & $0.42 \pm 0.07(24 *)$ & $19.6 \pm 0.9\left(40^{*}\right)$ & $15.1 \pm 0.6\left(40^{*}\right)$ & $10.2 \pm 0.8(40 *)$ & $9.0 \pm 1.2(24 *)$ \\
\hline \multicolumn{9}{|l|}{2008} \\
\hline Low \& N:P=1.7 & $1.36 \pm 0.09(38)$ & $1.36 \pm 0.09(38)$ & $0.58 \pm 0.06(39 *)$ & $0.94 \pm 0.04(41 *)$ & $7.5 \pm 0.4(38)$ & $4.4 \pm 0.2(38)$ & $5.6 \pm 0.5\left(39^{*}\right)$ & $9.5 \pm 0.8\left(41^{*}\right)$ \\
\hline 15 & $0.48 \pm 0.03\left(38^{*}\right)$ & $0.48 \pm 0.03$ & $0.30 \pm 0.04(38 *)$ & $0.57 \pm 0.03(42 *)$ & $12.8 \pm 0.6\left(38^{*}\right)$ & $8.5 \pm 0.3(38)$ & $11.8 \pm 0.8\left(38^{*}\right)$ & $12.0 \pm 0.7(42 *)$ \\
\hline 135 & $0.39 \pm 0.06\left(25^{*}\right)$ & $0.39 \pm 0.06\left(27^{*}\right)$ & $0.30 \pm 0.03(34 *)$ & $0.42 \pm 0.02(42 *)$ & $16.2 \pm 0.8\left(25^{*}\right)$ & $9.5 \pm 0.6\left(27^{*}\right)$ & $15.4 \pm 1.0\left(34^{*}\right)$ & $13.2 \pm 0.6(42 *)$ \\
\hline High \& N:P=1.7 & $1.57 \pm 0.08\left(33^{*}\right)$ & $1.57 \pm 0.08$ & $1.12 \pm 0.12(37)$ & $1.28 \pm 0.12\left(41^{*}\right)$ & $7.5 \pm 0.3\left(33^{*}\right)$ & $5.0 \pm 0.2$ & $6.1 \pm 0.6(37)$ & $8.4 \pm 0.5\left(41^{*}\right)$ \\
\hline 15 & $0.50 \pm 0.02\left(31^{*}\right)$ & $0.50 \pm 0.02$ & $0.23 \pm 0.03$ & $0.63 \pm 0.03(42 *)$ & $10.8 \pm 0.3\left(31^{*}\right)$ & $8.0 \pm 0.3(32)$ & $7.3 \pm 0.6(32)$ & $11.6 \pm 0.5(42 *)$ \\
\hline 135 & $0.39 \pm 0.04\left(25^{*}\right)$ & $0.39 \pm 0.04\left(28^{*}\right)$ & $0.38 \pm 0.06(34 *)$ & $0.54 \pm 0.03(42 *)$ & $20.1 \pm 1.1\left(25^{*}\right)$ & $12.0 \pm 0.7\left(28^{*}\right)$ & $21.2 \pm 1.5\left(34^{*}\right)$ & $11.8 \pm 0.5(42 *)$ \\
\hline
\end{tabular}

\section{References}

Aerts R, Chapin FSI (2000) The mineral nutrition of wild plants revisited: a re-evaluation of processes and patterns. Adv Ecol Res 30:1-67

Agren GI (2008) Stoichiometry and nutrition of plant growth in natural communities. Annu Rev Ecol Evol Systemat 39:153-170

Batten GD, Wardlaw IF (1987) Senescence and grain development in wheat plants grown with contrasting phosphorus regimes. Aust J Plant Physiol 14:253-265

Beltman B, Willems JH, Güsewell S (2007) Flood events overrule fertiliser effects on biomass production and species richness in riverine grasslands. J Veg Sci 18:625-634

Bobbink R, Hornung M, Roelofs JGM (1998) The effects of air-borne nitrogen pollutants on species diversity in natural and semi-natural European vegetation. J Ecol 86:717-738

Bremner JM, Mulvaney CS (1982) Salicylic acid-thiosulphate modification of Kjeldahl method to include nitrate and nitrite. In: Page AC, Miller RH, Keeney DR (eds) Methods of soil analysis; Part 2, Chemical and microbiological properties. American society of Agronomy, Madison, pp 621-622

Craine JM, Jackson RD (2009) Plant nitrogen and phosphorus limitation in 98 North American grassland soils. Plant Soil. doi:10.1007/s11104-009-0237-1
El-Kahloun M, Boeye D, van Haesebroeck V, Verhagen B (2003) Differential recovery of above- and below-ground rich fen vegetation following fertilization. J Veg Sci $14: 451-458$

Ertsen D (1998) Ecohydrological response modelling: predicting plant species response to changes in site conditions. Utrecht University, Utrecht

Fransen B, de Kroon H (2001) Long-term disadvantages of selective root placement: root proliferation and shoot biomass of two perennial grass species in a 2-year experiment. J Ecol 89:711-722

Fujita Y, Robroek BJM, de Ruiter PC, Heil GW, Wassen MJ (2010) Increased $N$ affects $P$ uptake of eight grassland species: the role of root surface phosphatase activity. OIKOS. doi:10.1111/j.1600-0706.2010.18427.x

Galloway JN (1995) Acid deposition: perspectives in time and space. Water Air Soil Pollut 85:15-24

Gordon WS, Jackson RB (2000) Nutrient concentrations in fine roots. Ecology 81:275-280

Güsewell S (2004) N:P ratios in terrestrial plants: variation and functional significance. New Phytol 164:243-266

Güsewell S (2005a) High nitrogen: phosphorus ratios reduce nutrient retention and second-year growth of wetland sedges. New Phytol 166:537-550

Güsewell S (2005b) Nutrient resorption of wetland graminoids is related to the type of nutrient limitation. Funct Ecol 19:344-354 
Güsewell S (2005c) Responses of wetland graminoids to the relative supply of nitrogen and phosphorus. Plant Ecol 176:35-55

Güsewell S, Koerselman W (2002) Variation in nitrogen and phosphorus concentrations of wetland plants. Perspect Plant Ecol Evol Syst 5:37-61

Güsewell S, Koerselman W, Verhoeven JTA (2002) Timedependent effects of fertilization on plant biomass in floating fens. J Veg Sci 13:705-718

Güsewell S, Bollens U, Ryser P, Klötzli F (2003) Contrasting effects of nitrogen, phosphorus and water regime on firstand second-year growth of 16 wetland plant species. Funct Ecol 17:754-765

Holland EA, Dentener FJ, Braswell BH, Sulzman JM (1999) Contemporary and pre-industrial global reactive nitrogen budgets. Biogeochemistry 46:7-43

Keddy P, Fraser LH, Keogh TA (2001) Responses of 21 wetland species to shortage of light, nitrogen and phosphorus. Bull Geobot Inst ETH 67:13-25

Kirkham FW, Mountford JO, Wilkins RJ (1996) The effects of nitrogen, potassium and phosphorus addition on the vegetation of a Somerset peat moor under cutting management. J Appl Ecol 33:1013-1029

Koerselman W, Bakker SA, Blom M (1990) Nitrogen, phosphorus and potassium budgets for two small fens surrounded by heavily fertilized pastures. J Ecol 78:428-442

Lambers H, Shane MW, Cramer MD, Pearse SJ, Veneklaas EJ (2006) Root structure and functioning for efficient acquisition of phosphorus: matching morphological and physiological traits. Ann Bot 98:693-713

Lamers LPM, Smolders AJP, Roelofs JGM (2002) The restoration of fens in the Netherlands. Hydrobiologia 478:107-130

Macek P, Rejmankova E (2007) Response of emergent macrophytes to experimental nutrient and salinity additions. Funct Ecol 21:478-488

Olde Venterink H, Pieterse NM, Belgers JDM, Wassen MJ, de Ruiter OD (2002) N, P and K budgets along nutrient availability and productivity gradients in wetlands. Ecol Appl 12:1010-1026

Olde Venterink H, Wassen MJ, Verkroost AWM, de Ruiter PC (2003) Species richness-productivity patterns differ between N-, P-, and K- limited wetlands. Ecology $84: 2191-2199$

Raghothama KG, Karthikeyan AS (2005) Phosphate acquisition. Plant Soil 274:37-49

Ryser P, Verduyn B, Lambers H (1997) Phosphorus allocation and utilization in three grass species with contrasting response to N and P supply. New Phytol 137:293-302

Shaver GR, Melillo JM (1984) Nutrient budgets of marsh plants: efficiency concepts and relation to availability. Ecology 65:1491-1510

Sokal RR, Rohlf FJ (1995) Biometry: the principles and practice of statistics in biological research. W.H.Freeman and Company, New York, p 887

Sterner RW, Elser JJ (2002) Ecological Stoichiometry: the biology of elements from molecules to the giosphere. Princeton University Press, Princeton, p 439

Stevens CJ, Dise NB, Mountford JO, Gowing DJ (2004) Impact of nitrogen deposition on the species richness of grasslands. Science 303:1876-1879

Treseder KK, Vitousek PM (2001) Effects of soil nutrient availability on investment in acquisition of $\mathrm{N}$ and $\mathrm{P}$ in Hawaiian rain forests. Ecology 82:946-954

van der Hoek D, van Mierlo AJEM, van Groenendael JM (2004) Nutrient limitation and nutrient-driven shifts in plant species composition in a species-rich fen meadow. $\mathrm{J}$ Veg Sci 15:389-396

Vance CP, Uhde-Stone C, Allan DL (2003) Phosphorus acquisition and use: critical adaptations by plants for securing a nonrenewable resource. New Phytol 157:423-447

Verhoeven JTA, Schmitz MB (1991) Control of plant growth by nitrogen and phosphorus in mesotrophic fens. Biogeochemistry 12:135-148

Wassen MJ, Olde Venterink H (2006) Comparison of nitrogen and phosphorus fluxes in some European fens and floodplains. Appl Veg Sci 9:213-222

Wassen MJ, Olde Venterink H, Lapshina ED, Tanneberger F (2005) Endangered plants persist under phosphorus limitation. Nature 437:547-550

Weishampel P, Bedford BL (2006) Wetland dicots and monocots differ in colonization by arbuscular mycorrhizal fungi and dark septate endophytes. Mycorrhiza 16:495-502 